\title{
What is the Impact of Burnout on Nurses Work Behavior in Nursing Care?
}

\author{
$1^{\text {st }}$ Esri Rusminingsih \\ Nursing Department \\ College of Health Sciences \\ Muhammadiyah Klaten \\ J1 Ir Soekarno KM 1 Buntalan 57419, \\ Indonesia \\ esrirusminingsih@yahoo.co.id \\ $4^{\text {th }}$ Marwanti \\ Nursing Department \\ College of Health Sciences \\ Muhammadiyah Klaten \\ J1 Ir Soekarno KM 1 Buntalan 57419, \\ Indonesia
}

\author{
$2^{\text {nd }}$ Istiqomah S.T \\ Nursing Department \\ College of Health Sciences \\ Muhammadiyah Klaten \\ J1 Ir Soekarno KM 1 Buntalan 57419, \\ Indonesia
}

\author{
$3^{\text {rd }}$ Romadhani TP \\ Nursing Department \\ College of Health Sciences \\ Muhammadiyah Klaten \\ J1 Ir Soekarno KM 1 Buntalan 57419, \\ Indonesia
}

\begin{abstract}
Work fatigue is one factor that can cause errors at work. Burnout is an individual problem that requires physical, mental, and emotional transition due to long-term stress. Burnout is a problem for organizations that cause a decrease in work productivity. The nurse is one of the health workers who determine the quality of service in the hospital. The high workload of nurses raises errors in the actions given to patients. Objective: was to determine the relationship between burnout with nurses' work behavior in the hospital. This research was conducted on nurses working in hospitals. The sampling technique uses proportional random sampling method with a total of 44 people. Retrieval of burnout data include three domains, emotional exhaustion, depersonalization, and personal achievement. Results: The average age of nurses was $\mathbf{2 6 . 0 9}$ years, women (84. 1\%), diploma education (97. 7\%), and worked for $1-5$ years $(\mathbf{7 7 . 3 \%})$. There is a relationship between burnout and nurse's work behavior ( $p$ value $<0.05$ ). The higher the emotional exhaustion, the decreasing nurse's work behavior $(r=-0,537)$. The higher the depersonalization, the lower the work behavior $(r=-0.687)$, the higher the personal achievement, the lower nurse's work behavior $(r=-\mathbf{0 . 4 3 9})$. Conclusion: There is a relationship between burnout and nurse's work behavior. The higher the emotional exhaustion, depersonalization and personal achievement, the nurse's work behavior decreases. The strongest close relationship is found in the depersonalization relationship with nurse's work behavior compared to other Burnout domains.
\end{abstract}

Keywords - burnout, nursing, behavior

\section{INTRODUCTION}

Nursing services are a major part of health services in hospitals. The amount of nurses associated with Nursing services is still limited, while nurses have a high workload. Nurses often get additional assignments among them completing the administration of patient returns, taking drugs, sending patients to radiology and so on. Professional nurses only use $46.3 \%$ of their time to work on nursing tasks [1]. The increase in non-nursing workloads cause task of providing nursing care ignored.
Nurse's work behavior is something that can be accepted by patients as recipients of care services. Poor nurse's work behavior causes a decrease in the quality services hospital in the eyes of consumers. The increased workload of nurses physically, mentally and emotionally known as Burnout. The effects arising from burnout are decreased motivation for work, cynicism, negative attitudes, frustration, feelings of rejection by the environment, failure and low self-esteem [2].

Burnout occurs due to changing psychological conditions of nurses due to adverse work reactions. Manifestations of these changes are in physical exhaustion, emotional exhaustion and mental exhaustion because they work in a framework that requires emotional involvement[3]. Burnout is a problem for organizations that cause decresed productivity[4]. Research by Maharani and Triyoga (2012) provides a conclusion that there is no relationship between burnout and nurse's work behavior because all nurses have good performance and sufficiently increases work saturation[5]. The increasing workload of nurses causes fatigue in work. Many studies indicate individual factors including age, years of service, marital status and nutrition cause fatigue[6]. High workloads can cause the risk of errors and reduce maintenance security. In addition, high workloads reduce the quality of nurses' work[7].

Work fatigue is one factor that decreases performance which can increase errors[8]. Work fatigue that cannot be overcome can lead to fatal work problems and accidents. In this regard, the Hospital requires a nurse workload analysis including additional non-nursing workloads which can cause performance degradation, decreased productivity and decreased service quality.

\section{METHOD}

This research is a correlation analytic study with a cross-sectional approach. The study population was all nurses in the adult inpatient ward. The study was 
conducted at PKU Muhammadiyah Delanggu Hospital in November to December 2018. PKU Muhammadiyah Delanggu Hospital is a type D hospital with 214 beds and a total of 137 nurses.

Sampling using proportional random sampling is taking a sample of nurses randomly based on the proportion of each in ward ward with a total of 44 respondents. Inclusion criteria:the respondent is nurse, working in a neighborhood in an adult ward,. The research instrument using the burnout questionnaire was adopted from Maslach's theory consisting of three categories namely fatigue, depersonalization and personal achievement. Data collection about Burnout is done by asking respondents to fill in the Burnout questionnaire. Nurse's work behavior measurements using the Koesinoer Performance Scale were adopted from Nursalam (2017)[9].
Nurses' performance appraisal is carried out using observation techniques involving research assistants who are heads of rooms in the ward. The research assistant was assessed by the Kappa test with the results of the Kappa coefficient $=0.693693>0.6$ and $p$ value $=0.000<0.05$. Data analysis to determine the relationship of burnout with nurse's work behavior using the Spearman's Rho test.

\section{RESULT}

In this study using 44 respondents. The average age of respondents in this study was 26.09 years with a standard deviation of 3.62. Based on the sex of the respondents, most were women $(84.1 \%)$. The majority of respondents had DIII Nursing education $(97.7 \%)$. Length of work worked as nurses for 1-5 years (77.3). Respondent characteristic data can be seen in table 1 and table 2 .

TABLE 1. SUBJECTS' CHARACTERISTICS

\begin{tabular}{|c|r|r|r|r|r|}
\hline $\begin{array}{c}\text { Characteristics of } \\
\text { respondents }\end{array}$ & $\mathrm{n}$ & $\begin{array}{r}\text { Minim } \\
\text { um }\end{array}$ & $\begin{array}{r}\text { Maxim } \\
\text { um }\end{array}$ & Mean & $\begin{array}{c}\text { Std. } \\
\text { Deviation }\end{array}$ \\
\hline Age & 4 & 23.00 & 43,00 & 26,0909 & 3.62047 \\
& 4 & & & & \\
\hline
\end{tabular}

TABLE 2. DISTRIBUTION FREQUENCY OF GENDER, EMPLOYMENT STATUS, EDUCATION, AND LENGTH OF WORK

\begin{tabular}{|l|l|c|c|}
\hline & Variable & F & Number \\
\hline & Gender & 37 & 84,1 \\
\hline & Female & 7 & 15,9 \\
\hline & Male & 41 & 93,2 \\
\hline & $\begin{array}{l}\text { Employment Status } \\
\text { Contract Worker }\end{array}$ & 3 & 6,8 \\
\hline & Nurse Officer & & 97,7 \\
\hline & Education & 43 & 2,3 \\
\hline & Diploma III Nursing & 1 & 9,1 \\
\hline & Bachelor Nursing & & 77,3 \\
\hline & Length of Work & 4 & 13,6 \\
\hline & $<1$ year & 34 & \\
\hline & 1-5 year & 6 & \\
\hline
\end{tabular}

Burnout measurement uses Maslach Burnout Inventory (MBI) which consists of three parts, namely burnout, depersonalization and personal achievement. The results showed that the majority of nurses experienced emotional exhaustion (burnout), depersonalization and personal achievement (personal achievement) in the moderate category of (52.3\%).
Burnout frequency distribution data can be seen in table 3.

The results showed that of the 44 respondents, the majority of respondents' performance was in the high category $(52.3 \%)$, moderate performance was $(34.1 \%)$ and at least it had a low performance (13.6\%). Performance data can be seen in table 4 .

TABLE 3. BURNOUT

\begin{tabular}{|l|l|c|c|}
\hline & Burnout & F & Number \\
\hline & Burnout & 3 & 6,8 \\
\hline & High & 23 & 52,3 \\
\hline & Middle & 18 & 40,9 \\
\hline & Low & & \\
\hline & Depersonalization & 8 & 18,2 \\
\hline & High & 23 & 52,3 \\
\hline & Middle & & \\
\hline
\end{tabular}




\begin{tabular}{|l|l|c|c|}
\hline & Low & 13 & 29,5 \\
\hline & Personal Achievement & & 20,5 \\
\hline & High & 9 & 52,3 \\
\hline & Middle & 23 & 27,3 \\
\hline & Low & 12 & \\
\hline
\end{tabular}

TABLE. 4. NURSE'S WORK BEHAVIOR

\begin{tabular}{|l|l|c|c|}
\hline & Nursing Performance & F & Number \\
\hline & Low & 6 & 13,6 \\
\hline & Middle & 15 & 34,1 \\
\hline & High & 23 & 52,3 \\
\hline
\end{tabular}

The results of the study using Spearman Rho at a 95\% confidence level prove there is a relationship between burnout (emotional fatigue sindrom) with nurse's work behaviour ( $p$ value $=0,000<0.05$ ) with a value of $r=$ 0.537 which means the higher the emotional fatigue, the lower the nurse's work behaviour. The results of the study are discussed in table 5.

There is a relationship of burnout (depersonalization) with the nurse's work behavior ( $p$ value $=0,000<0.05) r$
$=-0,687$, the higher the depersonalization, the lower the nurse's work behavior. Data can be seen in table 6 .

The results also show that there is a relationship between Personal Achievement and nurse's work behavior $(\mathrm{p}$ value $=0.003<0.05)$ with $\mathrm{r}=-0.439$ which means that the higher the personal achievement, the nurse's work behavior decreases.

TABLE.5 RELATIONSHIP OF BURNOUT WITH NURSE'S WORK BEHAVIOUR

\begin{tabular}{|c|c|c|c|c|c|c|c|c|c|c|}
\hline \multirow{3}{*}{$\begin{array}{c}\text { Burnout (Emotional } \\
\text { Fatigue Syndrome) }\end{array}$} & \multicolumn{6}{|c|}{ Nurse's work behaviour } & \multirow{2}{*}{\multicolumn{2}{|c|}{ Total }} & \multirow{3}{*}{$r$} & \multirow{3}{*}{$\begin{array}{c}p \\
\text { value }\end{array}$} \\
\hline & \multicolumn{2}{|c|}{ Low } & \multicolumn{2}{|c|}{ Middle } & \multicolumn{2}{|c|}{ High } & & & & \\
\hline & $n$ & $\%$ & $\mathrm{n}$ & $\%$ & $\mathrm{n}$ & $\%$ & $\mathrm{n}$ & $\%$ & & \\
\hline High & 3 & $6,8 \%$ & 0 & $0,0 \%$ & 0 & $0,0 \%$ & 3 & $6,8 \%$ & $-0,537$ & 0,000 \\
\hline Middle & 3 & $6,8 \%$ & 11 & $25 \%$ & 9 & $20,5 \%$ & 23 & $52,3 \%$ & & \\
\hline Low & 0 & $0,0 \%$ & 4 & $9,1 \%$ & 14 & $31,8 \%$ & 18 & $40,9 \%$ & & \\
\hline
\end{tabular}

TABLE .6 RELATIONSHIP OF DEPERSONALIZATION WITH NURSE'S WORK BEHAVIOUR

\begin{tabular}{|c|c|c|c|c|c|c|c|c|c|c|}
\hline \multirow{3}{*}{ Depersonalisation } & \multicolumn{6}{|c|}{ Nurse's work behaviour } & \multirow{2}{*}{\multicolumn{2}{|c|}{ Total }} & \multirow{3}{*}{$\mathrm{r}$} & \multirow{3}{*}{$\begin{array}{c}p \\
\text { value }\end{array}$} \\
\hline & \multicolumn{2}{|c|}{ Low } & \multicolumn{2}{|c|}{ Middle } & \multicolumn{2}{|c|}{ High } & & & & \\
\hline & $\mathrm{n}$ & $\%$ & $\mathrm{n}$ & $\%$ & $\mathrm{n}$ & $\%$ & $\mathrm{n}$ & $\%$ & & \\
\hline High & 3 & $6,8 \%$ & 5 & $11,4 \%$ & 0 & $0,0 \%$ & 8 & $18,2 \%$ & $-0,687$ & 0,000 \\
\hline Middle & 3 & $6,8 \%$ & 10 & $22,7 \%$ & 10 & $22,7 \%$ & 23 & $52,3 \%$ & & \\
\hline Low & 0 & $0,0 \%$ & 0 & $0,0 \%$ & 13 & $29,5 \%$ & 13 & $29,5 \%$ & & \\
\hline
\end{tabular}

TABLE 7 RELATIONSHIP OF PERSONAL ACHIEVEMENT WITH NURSE'S WORK BEHAVIOUR

\begin{tabular}{|c|c|c|c|c|c|c|c|c|c|c|}
\hline \multirow{3}{*}{ Personal Achievement } & \multicolumn{6}{|c|}{ Nurse's work behaviour } & \multirow{2}{*}{\multicolumn{2}{|c|}{ Total }} & \multirow{3}{*}{$\mathrm{r}$} & \multirow{3}{*}{$\begin{array}{c}p \\
\text { value }\end{array}$} \\
\hline & \multicolumn{2}{|c|}{ Low } & \multicolumn{2}{|c|}{ Middle } & \multicolumn{2}{|c|}{ High } & & & & \\
\hline & $\mathrm{n}$ & $\%$ & $\mathrm{n}$ & $\%$ & $\mathrm{n}$ & $\%$ & $\mathrm{n}$ & $\%$ & & \\
\hline High & 1 & $2,3 \%$ & 0 & $0 \%$ & 8 & $18,2 \%$ & 9 & $20,5 \%$ & $-0,439$ & 0,003 \\
\hline Middle & 1 & $2,3 \%$ & 10 & $22,7 \%$ & 12 & $27,3 \%$ & 23 & $52,3 \%$ & & \\
\hline Low & 4 & $9,1 \%$ & 5 & $11,4 \%$ & 3 & $6,8 \%$ & 12 & $27,3 \%$ & & \\
\hline
\end{tabular}

\section{DISCUSSION}

The results of the study of 44 respondents with an average age of 26.09 years with a standard deviation of 3,6205 years. Age under 30 years have a greater chance of experiencing burnout than at an older age. This is because at a young age they have little work experience [10]. Based on table 2, the sex of the respondents was mostly female $(84.1 \%)$, This is consistent with the results of Mariyanti and Citrawati's (2011) research which states that female nurses experience higher burnout compared to male nurses[11]. Suharti and Daulima's research (2013) also states that female nurses have a higher tendency to experience burnout than men[10]. Length of work worked as nurses for 1-5 years (77.3). Nurses who have a Length of Work (0-5 years) have a higher burnout score, compared to nurses who have a Length of Work of more than 20 years[12]

The results showed that of the 44 respondents, most of the nurses' performance was included in the high category 
(52.3\%). This result is supported by research of Suharti and Daulima (2013) which shows that most nurses have good performance.

Similarly, the results of the study of Hera et al (2016) in which nurses have a good ability to complete tasks and responsibilities[13]. Nurse performance is influenced by work motivation, work rotation, work discipline and reward.

The higher the work motivation, the better the performance. A work rotation of less than 5 years will improve performance[14]. The results of this study indicate that respondents agreed to emotional conversation in the moderate category $(52.3 \%)$.

The depletion of energy in providing nursing care reduces the reduction in emotional resources in themselves (feelings of love, empathy, attention), helplessness, stress, apathy towards work and shackled by tasks at work, which in turn causes feelings of being unable to provide services nursing[15]. The nurse's workload can be predicted from the clinical characteristics of the patient. There is a positive correlation between workload with the variable disease severity of patients[16] The results also prove that there is a relationship between burnout (emotional assessment) with nurse's work behavior ( $\mathrm{p}$ value $=0,000<0.05$ ) with $\mathrm{r}=-0.537$ which means the higher the burnout (emotional exhaustion), the lower the nurse's work behavior.

Some other research results also support the results of this study, which shows there is a relationship between Burnout and nurse's work behavior[10]. Majore et al (2018) also proved that there was a significant relationship between Burnout and nurses' performance in the inpatient room [17]. According to the results of Tri Ismu's research (2017) found that there was burnout in hospitals by 67.6\%[18]. Fatigue experienced by nurses will have a negative effect on patient care, work environment, high rates of nurse resignation[19]

Most nurses experienced depersonalization in the moderate category $(52.3 \%)$. This condition leads to the loss of empathy causing cynicism with negative attitudes toward patients or colleagues, feeling guilty, avoiding social contact and withdrawing. This syndrome is a further result of attempts to withdraw from emotional involvement with others. Other attitudes that emerge are the loss of idealism, reducing contact with the surroundings, relating only as needed, negative opinions and being cynical about the surroundings. Concretely, someone who experiences depersonalization tends to underestimate, make fun of, not care about other people being served, and be rude [15]. There is a relationship of burnout (depersonalization) with nurse's work behavior ( $\mathrm{p}$ value $=0,000<0.05) \mathrm{r}=-0,687$, the higher the depersonalization, the lower the nurse's work behavior.

Decreased personal achievement is a condition of nurses who accept themselves negatively. Most respondents of personal achievement are in the moderate category $(52.3 \%)$. There is a relationship between Personal Achievement with nurse's work behavior ( $p$ value $=0.003<0.05)$ with $r$ value $=-0.439$, which means the higher the Personal Achievement, the lower the nurse's work behavior. Nurses feel unsatisfied at work, feel incompetent, less satisfied with what has been done at work, even the feeling of failure at work[15]. Burnout reduction can be done by determining personal values and reducing the workload on contract nurses [20]. The hospital must be able to create a healthy work environment. Reduction of work fatigue can be done by adjusting the ratio of nurses: patients, management to create a good work environment and manage shorter work times[19].

\section{CONCLUSION}

There is a relationship between burnout and nurses work behavior. The higher the emotional exhaustion, depersonalization and personal achievement, the nurse's work behavior decreases. The strongest close relationship is found in the depersonalization relationship with nurses' work behavior compared to other Burnout domains.

\section{REFERENCES}

[1] Siedine K Coetzee and Hester Catharina Klopper, "Compassion fatigue within nursing practice: a concept analysis," Nurs. Health Sci., vol. 12, pp. 235-43, 2010.

[2] Irawati, "Faktor-faktor Karakteristik Yang Berpengaruh Terhadap Pelaksanaan Perilaku Hidup Bersih dan Sehat di Desa Tangunan Kecamatan Puri Kabupaten Mojokerto," J. Ilm. Kesehat. Politek. Kesehat. Majapahit, vol. 5, p. 134, 2014.

[3] C. Sucipto, Keselamatan dan Kesehatan Kerja. Yogyakarta: Gosyen Publishing, 2014.

[4] Dale, Memotivasi Pegawai, Seri Manajemen Sumber Daya Manusia. Jakarta: Elex Media Komputindo, 2011.

[5] A. Maharani, P.A. \& Triyoga, "Kejenuhan Kerja (burnout) dengan Kinerja Perawat dalam Pemberian Asuhan Keperawatan," J. Psikol., vol. 5, p. 167-178., 2012.

[6] Eralisa, "Hubungan Foktor Individu Dengan Kelelahan Kerja Pada Tenaga Kerja Bongkar Muat Di Pelabuhan Tapaktuan Kecamatan Tapaktuan Kabupaten Aceh Selatan," Fak. Kesehat. Masy. Univ. Sumatera Utara Medan, 2009.

[7] F. R. Shirazeh Arghami, Koorosh Kamali, "Task Performance induced Work Load in Nursing," Muhandisī-i bihdāsht-i hirfah/̄̄, vol. 2015;2(3):, pp. 45-54, 2015.

[8] E. Nurmianto, Ergonomi Konsep Dasar dan Aplikasinya. Bandung: ITSN, 2015.

[9] Nursalam, Manajemen Keperawatan, Aplikasi dalam Praktik Keperawatan Profesional. Jakarta: Salemba Medika, 2013.

[10] N. H. C. D. Suharti, Neli, "Burnout dengan Kinerja Karyawan di Rumah Sakit Metropolitan Medical Centre Jakarta," J. Penelitian. Fak. Ilmu Keperawatan Univ. Indones., 2013.

[11] A. C. Mariyanti, Sulis, "Burnout Pada Perawat Yang Bertugas Di Ruang Rawat Inap dan Rawat Jalan RSAB Harapan Kita," vol. 9, pp. 48-59, 2011.

[12] A. Khodadadizadeh, A. Ravari, and H. Jafarinaveh, "Occupational burnout assessment among nurses working in Iranian hospital of Ali-ebn Abitaleb , Rafsanjan- Iran,” no. July 2012, 2018.

[13] H. Hera, Rasyidin, "Pengaruh Konflik Peran Ganda, Beban Kerja Dan Kelelahan Kerja (Burnout) Dengan Kinerja Perawat Wanita di RSUD I Lagaligo Kabupaten Luwu Timur," J. Mirai Manag., vol. 1, pp. 119-135, 2016.

[14] A. Urus, A. Pongtiku, A. L. Rantetampang, and A. Mallongi, "The Factors Affecting Performance of Nurses at Sorong District Hospital," vol. 4, no. March, pp. 52-61, 2019.

[15] T. W. Sarafino, E. P., \& Smith, Health Psychology Eight Edition, 8th ed. USA: John Wiley \& Sons, Inc., 2014.

[16] J. G. Badia et al., "Nursing workload predictors in Catalonia (Spain): a home care cohort study Variables predictoras de las cargas de trabajo de enfermería en Cataluña: seguimiento de una 
cohorte de atención domiciliaria," Gac. Sanit. ISSN 0213-9111 (Print); 1578-1283, vol. 25(4), pp. 308-313, 2011.

[17] C. E. Majore and F. P. Kalalo, "Hubungan Kelelahan Kerja dengan Kinerja Perawat di Instalasi Rawat Inap RSU Pancaran Kasih GMIN Manado,” vol. 6, 2018.

[18] A. E. Tri Ismu Pujiyanto, Suprihati Suprihat, Nursalam, "IMPROVING NURSING WORK SERVICES THROUGH DEVELOPMENT MODEL OF QUALITY OF NURSING WORK LIFE," J. Ners, pp. 212-218, 2017.

[19] P. Holdren, D. P. P. Iii, and A. Coustasse, "Burnout syndrome in hospital nurses," 2015.

[20] N. K. DKAS Antara, N Nursalam, "Recommendation in Decreasing Burnout on the Contract Nurses," J. Ners, vol. 8, no. 142 , pp. 142-152, 2013. 